\title{
Architecture
}

\section{THE ROLE OF HERITAGE TOURISM IN PRESERVING HISTORICAL BUILDINGS IN PALESTINE (CASE STUDY OF THE PASHA'S PALACE, GAZA)}

\author{
Hammouda Nahed Aldohdar \\ Kharkiv National University of Civil Engineering and Architecture \\ Kharkiv, Ukraine
}

E-mail: dohdar.architect@gmail.com

\begin{abstract}
Introduction: Heritage tourism is often rooted by historic buildings. These powerful, tangible connections to our past are the ways in which people today come in touch with the past. Heritage buildings are also increasingly accepted as important venues linking a new generation with an older one, and thus as places to be used for heritage tourism. Revitalizing old neighborhoods - the buildings and the landscape - ensures that our quality of life is improved and that community cohesion is maintained. The Palestinian city of Gaza is mainly associated with conflicts and wars; however, its cultural side is typically hidden behind that news. But decades of uprisings, war and political turmoil have inflicted a heavy toll on its rich archaeological heritage, exposing it to looting and destruction. Methods: This article follows the scientific and engineering analysis as a way to deal with the mentioned problem by studying different factors affecting the architectural heritage of the Pasha's Palace in Gaza. Results and discussion: The article analyzes the functions of the complex, identifies and systematizes factors affecting the architectural and archaeological heritage of the old city of Gaza, and discusses the pros and cons of using the Al-Pasha Palace complex as a museum based on the strategies of the Burra Charter.
\end{abstract}

\section{Keywords}

Heritage tourism, conservation, maintenance, restoration, adaptation.

\section{Introduction}

The city of Gaza is considered one of the oldest cities. A sliver of land on the Mediterranean, Gaza was a major trade route between Egypt and the Levant going back to ancient times, with its roots extending to the third millennium BC (Lembaund, 1987; Suwaidan, 2004). The city was a cradle for many civilizations, including Canaanite, up to the Byzantine and Christian periods, and then to the Islamic era and subsequent periods, i. e. the Mamluk and Ottoman periods. All these periods have affected its development and left us a unique legacy and cultural heritage represented by numerous historical buildings. Throughout history, wars caused much destruction to archaeological and historical sites (Alnmara and Al-Qeeq, 2010). The Gaza Strip stays in the headlines with tragic regularity, while fabulous archaeological riches become buried under the ground. Despite the fact that indiscriminate violence destroyed some parts of the city, there are still historical attractions and landmarks to be seen. Palaces are the most important buildings of the Islamic architecture, characterized by unique methods of construction, art, decoration and inscriptions. Besides, they represent an impressive record of all stages of Islamic architecture development, particularly in Palestine.

Methods

Over time, we may lose some part of the cultural heritage since many ancient buildings and structures are built of sandstone. Sandstone and marble are the main materials that were used in Gaza city in antiquity to construct buildings, make sculptures to decorate facades, etc. However, such buildings are exposed to environmental damage (Palestinian Government, 1947). Besides, repeated wars have the biggest role in destroying cultural heritage, especially the Pasha's Palace complex.

The study focuses on the urban and architectural character of the Pasha's Palace in Gaza city and the factors that affected the complex (political, economic and social factors).

The study addresses the architectural and functional transitions of the Pasha's Palace in Gaza city during different historical periods from the Mamluk period until the end of the $20^{\text {th }}$ century. At the beginning of the $21^{\text {st }}$ century, it was rehabilitated as a museum. The article presents a detailed study of the monument use throughout history and describes the extent, to which it was affected by various political, economic, cultural and social factors. After the analysis and evaluation of the Pasha's Palace study results, we will offer some recommendations helping to save this important historical monument from extinction.

The purpose of the study is to analyze the impact of adverse environmental factors on the preservation of cultural heritage and examine research methods for 
the preservation of the architectural and archaeological heritage of the Al-Pasha Palace complex. The corresponding tasks include: consideration of the main anthropogenic and natural factors destroying cultural heritage; consideration of measures used for the preservation of cultural heritage.

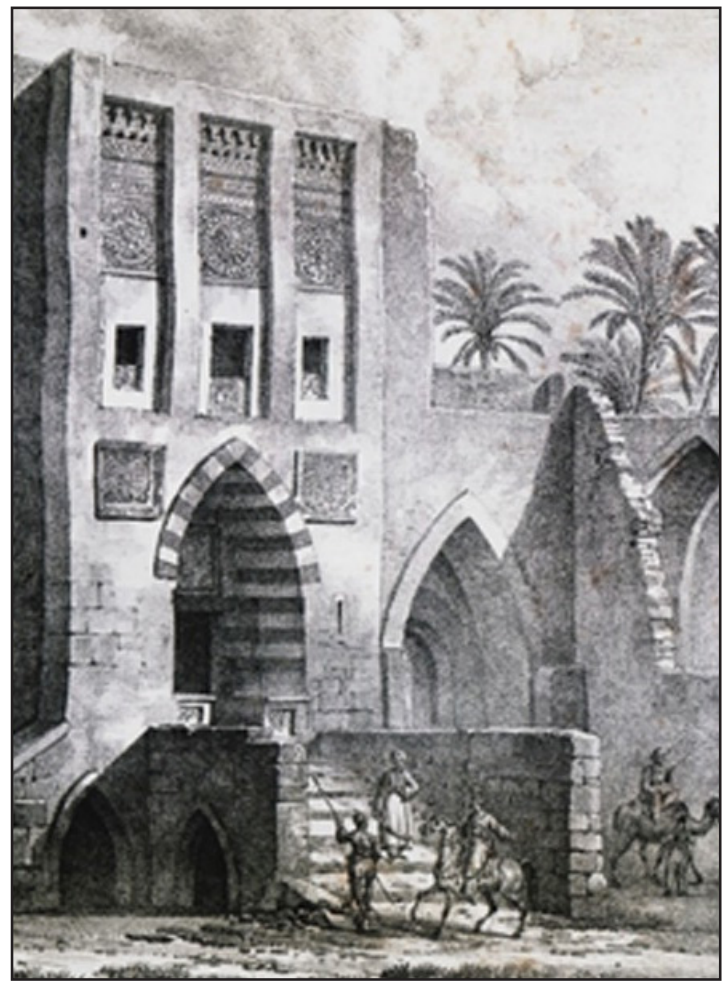

Figure 1. Qasr al-Ridwan (Pasha's Palace). Lithograph, 1819 (Travelogues, 2014).

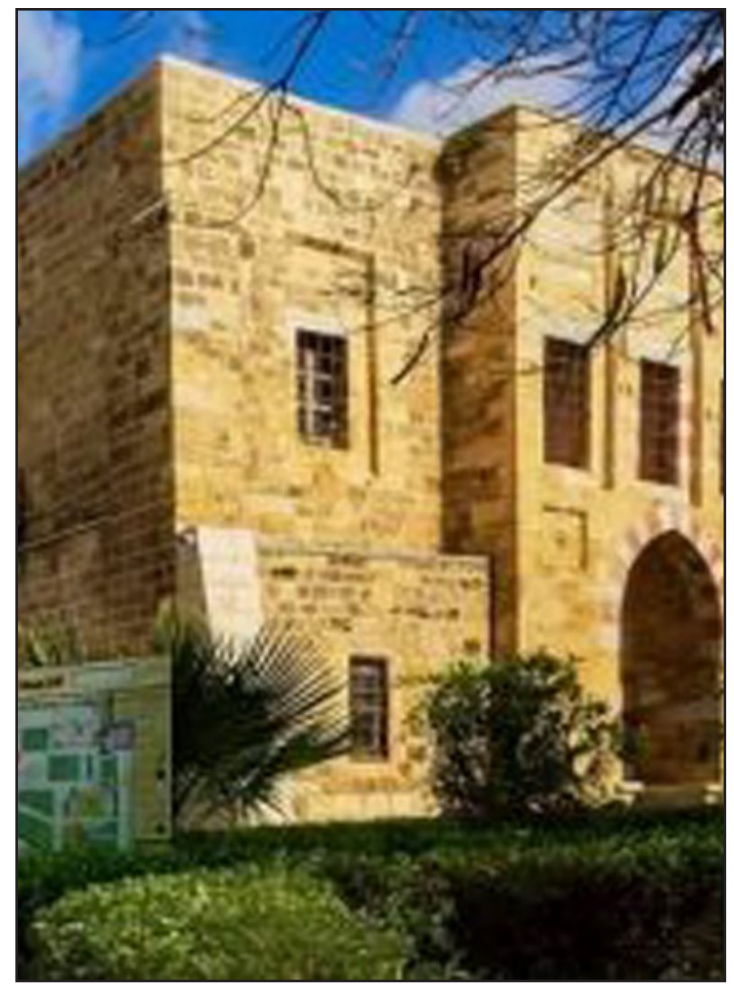

Figure 2. Pasha's Palace, 2020 (Ministry of Tourism and Antiquities, 2013).

\section{Objectives:}

1. To identify features for the formation of a scientific approach to the restoration of monuments of Arab architecture and determine the degree of knowledge regarding the architectural and archaeological heritage of Gaza (e.g. regarding the Al-Pasha Palace complex).

2. To identify stages of Al-Pasha Palace complex evolution.

3. To analyze the experience in implementing programs to preserve the heritage of Palestine, taking into account regulatory documents adopted at the international and national level (in particular, the United Nations Development Program (UNDP) for the transformation of the Pasha's Palace into a museum).

\section{Subject matter of the study}

The Al-Pasha palace (also known as the Palace of Al-Radwan) having the features of the Mamluk era is located in the Daraj district in the eastern part of old Gaza. This district is considered the richest in having historical buildings in the city. The palace reflects traditions, signs of the civilization and progress witnessed there in earlier times.

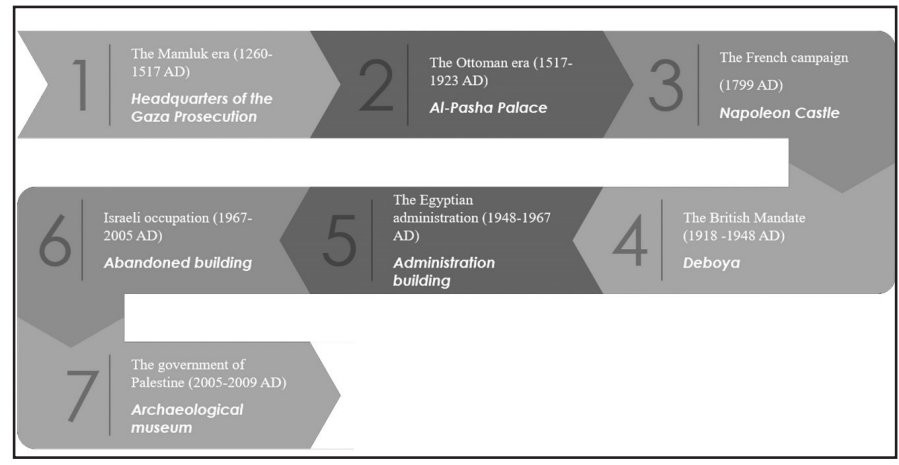

Figure 3. Historical stages of Al-Pasha Palace complex evolution (Ministry of Tourism and Antiquities, 2013).

Architectural description of the palace. The way this palace was built represents the philosophy and features of Islamic architecture. The complex includes two separate buildings with a yard in between, in addition to the front yard of the two-story old building.

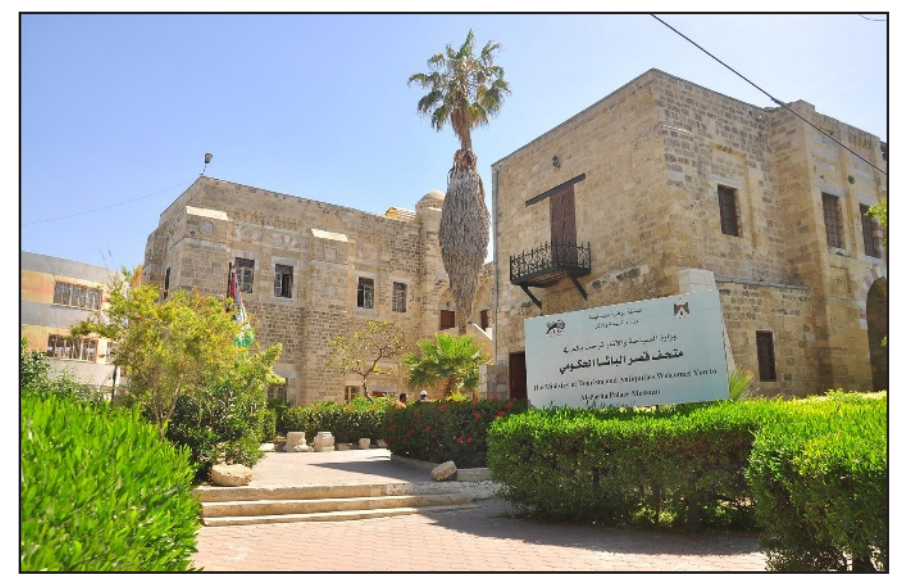

Figure 4. Pasha's palace (Ministry of Tourism and Antiquities, 2013). 


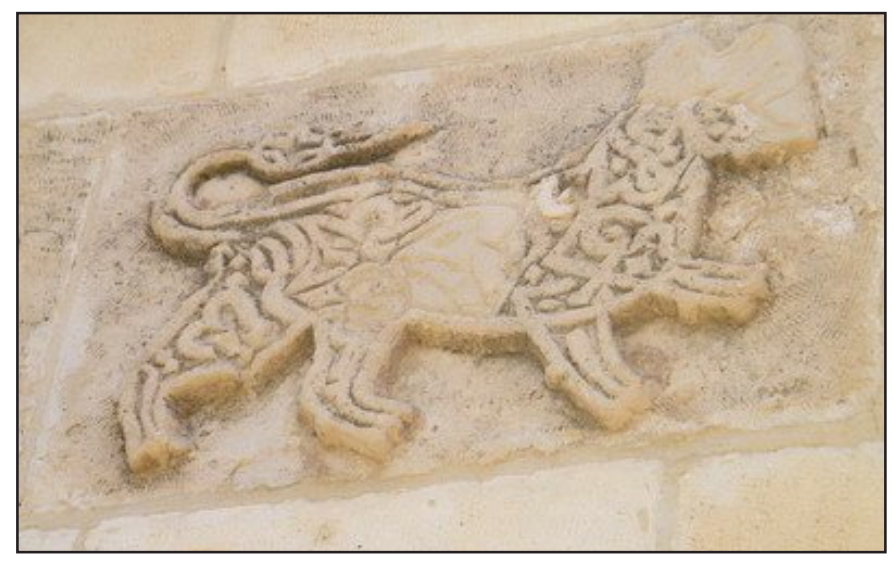

Figure 5. The lion's emblem, the Mamluk period (Ministry of Tourism and Antiquities, 2013).

The architectural elements that signify the building are represented by geometrical decorations in the fronts and entrances (Fayad, 2010). Various shapes (mostly star shapes and sharp curves) give prominence to the frames of the entrances. The main entrance to the palace is located on the southern facade of the northern building. It is decorated with beautiful geometric motifs inscribed in stone, particularly, with a rectangle stone with an image of two lions on the two sides, which is the symbol of the fourth Mamluk Sultan, Al-Zaher Baybars. Baybars was one of the military commanders in the battle of Ain Jalut, during which the Mamluk forces defeated the Mongols in 1260. The Mamluks were a Muslim dynasty that ruled Egypt and much of the Levant from their base in Cairo from the $13^{\text {th }}$ through the $15^{\text {th }}$ centuries.

The second story is largely Ottoman construction. The Pashas of Gaza administered their realm from this palace following the rapid conquest of the Middle East by the Ottomans during the late $15^{\text {th }}$ and early $16^{\text {th }}$ centuries. The second floor of the two buildings can be reached through external stairs for each building. Studies show that there is an underground floor requiring renovation under the southern building that disappeared and was covered by soil.

Influence of political factors on the buildings of the Pasha's Palace complex throughout history: The AlPasha Palace was exploited by occupiers during different historical stages of Gaza city since it is one of the largest and most beautiful buildings in the city (Wafa, 2005) This made the palace a target for destruction during military conflicts, which affected its architectural and planning structure.

1. It was exploited during the Mamluk era (1260-1517 $\mathrm{AD}$ ) as the headquarters of the Gaza Prosecution (military headquarters).

2. During the Ottoman era (1517-1923 AD), it was the governor's residence (Al-Pasha Palace).

3. In 1799 AD, the Pasha's Palace was occupied by the French campaign for a few days (Napoleon Castle).

4. During the period of the British Mandate of Palestine (1918-1948 AD), it was a police station (called Deboya).

5. During the rule of the Egyptian administration in Gaza (1948-1967 AD), it was used as a school administration building.
6. During Israeli occupation (1967-2005), it was abandoned but served as a target during conflicts and wars.

7. During the rule of the Palestine government (20052009), it was abandoned but since 2010 is has been used as an archaeological museum.

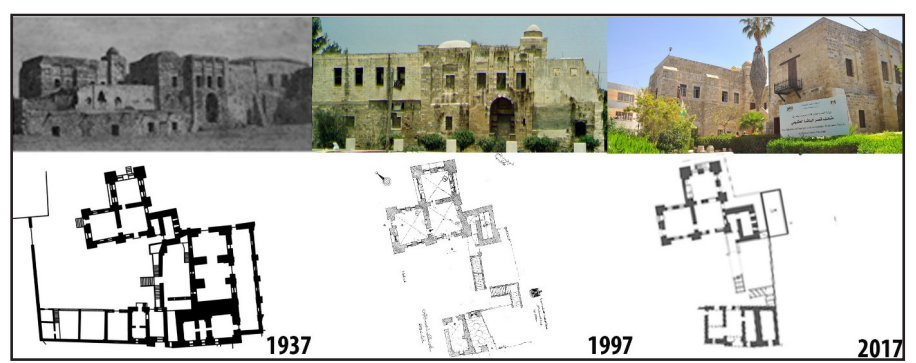

Figure 6. Buildings of the Al Pasha Palace complex affected by war.

Role of international and local institutions in the preservation of the historical monument:

1. Role of international institutions in the preservation of the historical monument: Within the United Nations Development Program (UNDP), a project was funded by a grant from the German Development Bank (KfW) for the transformation of the Pasha's Palace into a museum (Mitri Abu Aita, 2004). During the first phase of the project, workers landscaped the museum grounds, installed new doors, windows and gates, and restored the facade of the Pasha's Palace. In the second phase of the project, display cases and other appropriate furniture were installed in the museum. The smaller building in front of the palace was also renovated for use as a gateway to the museum.

2. Role of local institutions in the preservation of the historical monument: The Ministry of Tourism and Antiquities seeks to exercise its primary function of preserving and consolidating the features of Palestinian civilization and culture. The ministry uses its best efforts to ensure the success of the project in partnership with the UNDP Foundation.

Methods of building conservation (Australia ICOMOS, 1999). According to the Burra Charter, there are five main strategies in conservation:

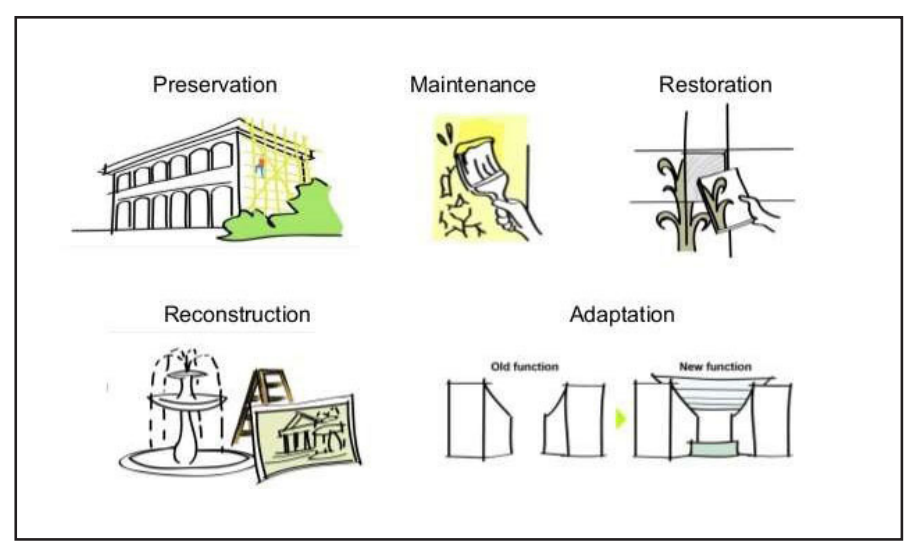

Figure 7. Methods of building conservation (Australia ICOMOS, 1999). 
The project for the restoration and rehabilitation of the Pasha's Palace in 2015:

1. Restoration of the northern building of the palace complex.

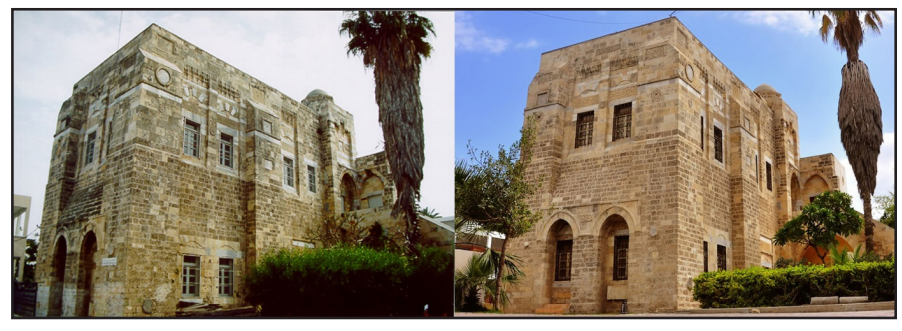

Figure 8. Northern building of the Pasha's Palace complex before and after restoration (Ministry of Tourism and Antiquities, 2013).

2. Restoration of the southern building of the palace complex.

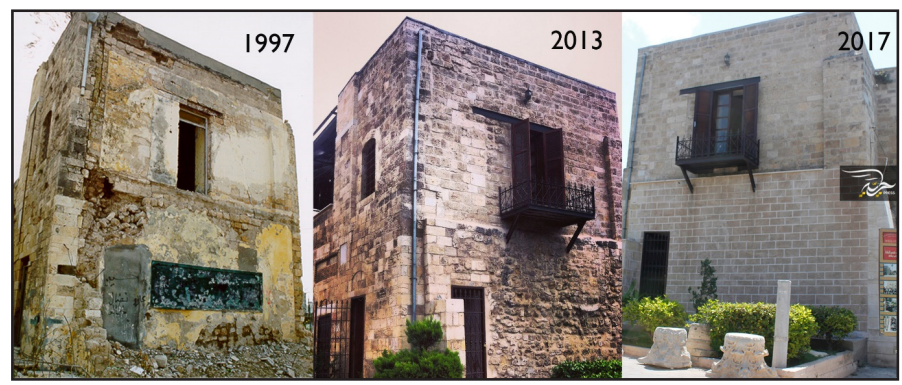

Figure 9. Southern building of the Pasha's Palace complex before and after restoration (Mitri Abu Aita, 2004).
Benefits of heritage building conservation: The preservation of heritage buildings is a vital component of urban revitalization efforts. The conservation of heritage buildings can help us all in an impressive variety of ways.

\section{Results and discussion}

1. We identified the historical stages of Al-Pasha Palace complex evolution in the $20^{\text {th }}$ century as a result of repeated wars.

2. We analyzed the experience in the restoration and preservation of the architectural and archaeological heritage of Gaza through the rehabilitation of the Al-Pasha Palace complex.

3. We studied the experience of joint activities of national and international organizations in implementing comprehensive programs for the restoration of the architectural and archaeological heritage in the historical cities of Palestine (in particular, the United Nations Development Program (UNDP) for the transformation of the Pasha's Palace into a museum).

4. We identified and systematized factors affecting the architectural and archaeological heritage of the old city of Gaza, represented by aspects of the political, environmental, social and economic nature.

5. We emphasized the importance of the rehabilitation of the monument as a national museum to highlight its historical significance.

6. We also identified possible pros and cons, constraints, and effects of strategies in building conservation according to the Burra Charter with regard to the Pasha's Palace.

Below we discuss the possible pros and cons, constraints, and effects of such strategies:

Table 1. Pros and cons of the strategies for the Pasha's Palace Museum (Gaza) according to the Burra Charter.

\begin{tabular}{|c|c|c|}
\hline Pasha's Palace Museum & Pros & Cons \\
\hline 1. Preservation & $\begin{array}{l}\text { The building form as it has } \\
\text { evolved over time can be } \\
\text { retained. }\end{array}$ & $\begin{array}{l}\text { Less flexibility: it may be more difficult to accommodate } \\
\text { future development since the building's existing state } \\
\text { has to be preserved (this applies especially to its use as } \\
\text { a museum). }\end{array}$ \\
\hline 2. Maintenance & - Stabilizes building conditions. & $\begin{array}{l}\text { Maintenance cannot solve any severe structural } \\
\text { problems and it is also costly (due to the siege and } \\
\text { economic problems of Gaza city). }\end{array}$ \\
\hline 3. Restoration & $\begin{array}{l}\text { Restores the property to an } \\
\text { architecturally 'pure' state } \\
\text { and therefore is a better } \\
\text { representation of a particular } \\
\text { historical era. Cultural value } \\
\text { can be fully reflected. }\end{array}$ & $\begin{array}{l}\text { - It is common to alter a building to reuse it. These } \\
\text { alterations can also be considered part of the building's } \\
\text { history and often reflect the aesthetics of certain periods. } \\
\text { To what extent should such alterations be tolerated and } \\
\text { preserved? } \\
\text { - May require techniques or materials that are lost or hard } \\
\text { to find. } \\
\text { Technically challenging. }\end{array}$ \\
\hline 4. Reconstruction & $\begin{array}{l}\text { Facilitates interpretation by } \\
\text { recreating important structures } \\
\text { or details. }\end{array}$ & $\begin{array}{l}\text { - New material is introduced. } \\
\text { - The authenticity of the building is lowered. }\end{array}$ \\
\hline 5. Adaptation & $\begin{array}{l}\text { The building can function as } \\
\text { part of society rather than } \\
\text { staying as an abandoned } \\
\text { building. }\end{array}$ & $\begin{array}{l}\text { - Changes in structure may have to be made. The } \\
\text { authenticity of the building is lowered. }\end{array}$ \\
\hline
\end{tabular}




\section{References}

Aldohdar, H., Cherkasova, K.T. (2019). Approaches to preserving the cultural heritage of archaeological buildings from the risks of repeated wars in the city of Gaza - Palestine (Example: reconstruction and restoration of the Al-Kozomri Mosque). International Journal of Scientific and Engineering Research, 8 (89), pp. 91-97.

Alnmara, Nader and Al-Qeeq, Farid (2010). The reality of the urban heritage of Gaza City in light of wars and natural disasters. The Second International Conference on Architectural Conservation, from 18 to 20 April 2010, Gaza, Palestine.

Al-Qeeq, Farid (2011). A Comprehensive Approach to Incorporate Architectural Heritage of Gaza Old City into Contemporary Urban Fabric. Journal of Art and Architectural Research: LONAARD, 1 (2).

Australia ICOMOS (1999). The Burra Charter. The Australia ICOMOS Charter for Places of Cultural Significance. [online] https:// australia.icomos.org/wp-content/uploads/BURRA_CHARTER.pdf (accessed on: 26.11.2019).

Fayad, A. (2010). Pasha's Palace tells the history of Gaza. Report in Arabic - Maliha, Nabila, Department of Culture, Al Jazeera Media Network, Doha, Qatar. [online] Available at: https://www.aljazeera.net/news/cultureandart/ (accessed on: 27.02.2010).

Lembaud, Salim (1987). Gaza and its sector. Immortality of the place - and the civilization of the population. From the Neolithic to the First World War. Egyptian General Book Association, Cairo, Egypt (Book Style).

Ministry of Tourism and Antiquities (2013). Sham Gate (archaeological guide). Department of Antiquities and Cultural Heritage, Gaza, Palestine, 102 p. [online]. Available at: www.mota.ps. (accessed on: 27.02.2015).

Mitri Abu Aita, H. E. (2004). The Pasha's Palace Museum (Gaza). Focus Journal. Cultural Heritage, 1, pp. 18-19.

Muhaisen, S. Ahmed (2016). Development of the House Architectural Design in the Gaza Strip. Athens Journal of Architecture. 2 (2), pp. 131-150.

Namara, N. E. (2014). A Proposed Approach for the Rehabilitation of Historical Buildings Possessing a Special Value in Gaza City Hammam Alsamra as a Case Study. Al-Qadisiyah Journal of Engineering Sciences, 7 (4), pp. 134-160.

Palestinian Government (1947). Gaza G. XI. ancient and medieval buildings and the foundation in the city. Vol. 2. Restoration projects report. London: Moore's Modern Methods, Ltd.

Suwaidan, Tareq (2004). Palestine ... Illustrated History. Publisher intellectual creativity, Kuwait, Kuwait. (Book style).

Travelogues (2014). Qasr al-Basha palace, Gaza. 1918. The Gennadius Library - The American School of Classical Studies at Athens. [online] Available at: https://tr.travelogues.gr/tag.php?view=9521 (accessed on: 15.12.2014).

Wafa (2005). Opening of the Al-Pasha Palace and exhibition of the Jerusalem photo in Gaza. [online] Available at: http://www. wafa.ps/ar_page.aspx?id=PWo6BCa30130596474aPWo6BC (accessed on: 08.06.2005). 